\title{
MUSIEKTERAPIE IN DIE OPLEIDING EN OPVOEDING VAN GEESTESVERTRAAGDES
}

\section{ELVERA THOMAS}

\section{B.A., M.Sc., U.T.L.M. Musiekterapeut}

\section{SUMMARY}

Music therapy involves the planned and controlled use of music to improve the quality of life of the person. It has a deffnite place in the education and training of mentally retarded persons.

Various behaviours and concepts can be taught through music, improving both social behaviour and eventually learning ability. Rhythmic movement to music can also improve phvsical health and music can have a calming infuence in stressful situations.

\section{INLEIDING}

Die invloed van musiekterapie in opleiding en opvoeding kan beide direk en indirek wees. Alle opvoeding, in die wydste sin, is terapeuties en alle vorme van behandeling wat die naam van terapie waardig is, moet die toestand van die gestremde persoon wat behandel word, verbeter. Aangesien die liggaam en die gees onafskeidbaar is, moet die behandeling van die een die toestand van die ander verbeter, en die verbetering van albei in aangeleerde en adaptiewe gedrag beteken vooruitgang in die ontwikkeling van kinders en volwassenes. Die gebruik van musiekterapie vir die geestesvertraagde het alreeds verder ontwikkel as enige ander terapeutiese gebruik van musiek.

\section{DEFINISIE VAN MUSIEK- TERAPIE}

Musiekterapie is die beplande en gekontroleerde gebruik van musiek om die hele bestaan van die persoon te bevoordeel. Musiekterapie sal spesifieke voordele aan individuele gevalle bied en die musiekterapeut sal suksesvolle metodes wat reeds oorsee ontwikkel is bestudeer en toepas. Hy/sy sal ook die ander lede van die terapeutiese span behulpsaam wees deur inligting aan hulle te verskaf ten opsigte van die gedrag van individue gedurende musiekperiodes, waar hulle alleen met die terapeut verkeer of anders in kleiner of groter groepe is.

\section{DEFINISIE VAN GEESTES- VERTRAGING - TWEE DIMENSIONAAL}

Geestesvertraging kan beskryf word as ondergemiddelde algemene verstandelike funksionering wat gedurende die ontwikkelingsperiode ontstaan en wat geassosieer word met benadeling van adaptiewe gedrag. Die twee dimensies is naamlik verlaagde verstandelike funksionering en verswakte sosiale aanpassing ${ }^{1}$.

'n Eenvoudige definisie is dat die verstandelike ouderdom of vlak van intelligente gedrag van 'n geestesvertraagde, laer is as sy werklike ouderdom volgens sy geboortedatum (chronologiese ouderdom). Die gemiddelde gedrag van normale kinders op sekere ouderdomme is reeds waargeneem en aangeteken. As 'n kind hom dus byvoorbeeld soos een van vier jaar gedra, word sy verstandelike ouderdom op vier jaar gestel. As sy werklike ouderdom dus tien jaar is, word sy intelligensiekwosiënt (volgens definisie) soos volg bereken: IK $=\frac{\text { Verstandelike ouderdom } \times 100}{\text { chronologiese ouderdom }}$

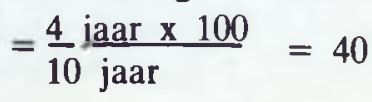

Vir pasiënte wat nie kan praat nie en wat oor 'n lae intelligensie beskik word 'n sosiale kwosiënt gebruik. Die sosiale ouderdom word volgens bewegingsvermoë, selfhulp, eetgewoontes en baie ander faktore op 'n maandelikse ouderdomsbasis bereken. So word die Vineland Social Maturity Scale volgens die normale gedrag van kinders tot by die ouderdom van omtrent vyf jaar gradeer.

\section{DIE INVLOED VAN MUSIEK- TERAPIE OP DIE SOSIALE KWOSIËNT}

Volgens 'n artikel in die SuidAfrikaanse Mediese Tydskrif van 17 Augustus 1974, is daar by die Alexandra Inrigting in 1973 bewys dat die sosiale kwosiënte van 'n groep erg geestesvertraagde seuns oor 'n tydperk van drie maande betekenisvol verbeter het met die toepassing van musiekterapie. Een pasiënt het by hertoetsing ' $n$ vermeerdering van 22 tot 41 in sy intelligensiekwosiënt getoon en kon gevolglik in die opleidingsentrum opgeneem word'. ('n Opsomming van hierdie verslag is in Amerika in Rehabilitation Literature Deel 36 no 1 gepubliseer). 
DIE INVLOED VAN MUSIEKTERAPIE OP GEDRAG EN DIE INVLOED VAN GEDRAG OP DIE LEERVERMOË

Gedrag word aangeleer maar ontstaan ook as gevolg van aanpassing by maatskaplike gemiddeldes, en as adaptiewe gedrag verbeter kan word deur byvoorbeeld die tydsduur van die pasiënt se aandag te verleng of sy verstandelike konsentrasie te verhoog, sal die vertraagde sekere vaardighede makliker as voorheen kan aanleer. Dit is tydgeoriënteerde gedrag en sluit opvolging in wat in musiek plaasvind wanneer geleer word om 'n instrument te bespeel deur op 'n gegewe teken in te val en weer op te hou. 'n Hiperaktiewe pasiënt sal leer dat om sonder ophou in 'n orkesgroepaktiwiteit te speel, nie aanvaarbaar is nie, en musikale dissipline leer hom om op sy beurt te wag. As hy weier om sy samewerking te gee, word sy musiekinstrument verwyder. Wanneer 'n groep met verskillende musiekinstrumente soos tromme, triangles en kastanjette gerangskik word, moet elke kind op die regte plek sit en die instrument wat aan hom gegee word, bespeel.

$\mathrm{Na}$ 'n paar sessies verbeter die gedrag aansienlik en bespeel die kind die instrument op die regte oomblik en so lank as wat die dirigent dit volgens die musiek vereis. Aan die einde van die musieksessie speel elkeen gewoonlik sy instrument so hard as moontlik om spanning te verlig.

\section{DIE DIREKTE .BYDRAE VAN MUSIEK TOT DIE OPVOE- DING VAN GEESTESVER- TRAAGDES}

Daar is baie begrippe wat maklik deur normale kinders verstaan word, maar wat in die geval van geestesvertraagdes baie meer intensiewe en konstruktiewe onderrig vereis. Nuwe metodes kan deur middel van musiek toegepas word, waar ander metodes ongeslaagd was.

\section{Ruimtelike begrippe}

In daaglikse kommunikasie is dit noodsaaklik dat rigting en ruimtelike posisie bekend moet wees, by- voorbeeld Gaan met die trap op. Neem dit na die kombuis. Plaas die vurk aan die linkerkant van die bord. Daar is 'n vragmotor agter jou! Was jou gesig. Droog jou voete af.

'n Kind leer die plasing of posisie van voorwerpe eers deur middel van sy eie liggaam, sy liggaamsdele en hul bewegings. Die geheue beheer spier- of motoriese aktiwiteit in aangeleerde gedrag. Musiek met beweging en woorde van aksieliedjies help hiermee, byvoorbeeld Die dak is bo-op hierdie mooi klein huisie, die voordeur is aan die voorkant en die agterdeur is aan die agterkant. Staan op en juig as jy Jesus liefhet, gaan sit en fluister as jy die Here liefhet. (Sodoende word die begrip van hard en sag ook ingevoer).

Op en af kan ook met musikale klanke van 'n hoë of lae toonhoogte geassosieer word, byvoorbeeld 'n hoë noot wat op die manuaal van 'n orrel gespeel word en 'n lae noot op die pedale. In die vorm van 'n speletjie kan die kinders gevra word om, deur te wys na 'n hoë voorwerp soos 'n musiekstaander, of 'n lae voorwerp soos 'n vloermat, aan te dui of die toonhoogte van 'n klank hoog of laag is. Hulle moet nie kan sien watter noot gespeel word nie.

Wat betref die verandering van posisie in ruimte, is die begrippe van vinnig en stadig ook belangrik vir veiligheid in verkeer. Hier kan daar ook van 'n oefening met musiek in die vorm van 'n speletjie gebruik gemaak word om begrippe van ruimte en rigting tuis te bring. 'n Pasiënt word geblinddoek in die rondte gedraai en word dan aangesê om 'n musikale klank te vind, byvoorbeeld note wat saggies op 'n klavier of ander instrument gespeel word. Hierdie speletjie behou die aandag van 'n kamer vol kinders, behalwe nog die een wat die klank moet opspoor. Dit kan in 'n siekesaal in 'n hospitaal gespeel word met behulp van 'n kassetopnemer, ' $n$ radio of enige draagbare of ander musiekinstrument.

\section{Gehoordiskriminasie, ontwik- keling van spraak- en dowe-terapie}

Aangesien die vermoë om te praat gewoonweg deur kinders aangeleer word deur te luister na spraak en spraak die belangrikste metode van kommunikasie in die lewe is, lewer enige opleiding in die vermoë om te luister 'n bydrae tot beter kommunikasie en sosiale verkeer. Die vermoë om te hoor is nie dieselfde as om te luister nie. Die ore sluit nie soos die oë wanneer daar gerus word nie en bied 'n belangrike verdedigingsmeganisme as die ander sintuie sluimer. As die ore gedurig deur harde gerase gestimuleer word, kan doofheid ontstaan ${ }^{3}$. Selfs aanhoudende sagte agtergrondmusiek sal intelligente luistervermoë afstomp. Die ontwikkeling van die oor deur met aandag na musikale klanke - waarvan die musiekterapeut die frekwensie ken - te luister, word in oudio-psigo-fonologie aan die Potchefstroomse Universiteit vir $\mathrm{CHO}$ en die Witrand Sorgen Rehabilitasiesentrum gebruik om hakkel en ander spraakgebreke te genees ${ }^{4}$.

Gehoorgebreke is dikwels slegs gedeeltelik aangesien die onvermoë om sekere frekwensies waar te neem, as gevolg van skade aan 'n deel van die middel- of binneoor, meebring dat woorde of klinkers nie korrek gehoor en gevolglik nie korrek weergegee kan word nie. Indien gehoorgebreke vermoed word, sal 'n oudiogram die gebrekkige frekwensie aandui wat dan deur die opgeleide musiekterapeut gestimuleer kan word. As gevolg van die verbetering in die gehoor sal die spraak ook verbeter. Daar is by die Alexandra Sorg- en Rehabilitasiesentrum en by verskeie ander inrigtings bewys dat wanneer 'n kind 'n viool en 'n klavier of fluit afsonderlik sien en hoor speel en dit dan op 'n plaat of bandopname hoor, hy die instrument wat bespeel word sal kan uitken. Die herkenning van die toonkwaliteite van verskillende instrumente vereis dat daar op gehoordiskriminasie gekonsentreer word. Die ontwikkeling van spraak, sodat een woord van die ander afgesonder word, is ook belangrik om die betekenis van die woord te begryp. Die instelling van die stembande om dieselfde toonhoogte as 'n musikale noot te verskaf sowel as die aanpassing by 
die tempo en ritme, word deur koorsang bevorder.

Die plesier wat sang aan die groep verskaf, word nog verder verhoog deur die geleentheid vir optrede in konserte binne en buite die inrigting, die goedkeuring en waardering van die publiek en die koek en tee wat bedien word!

\section{Die onderrig van die lees en skrywe van alfabetiese letters aan onbeheerbare kinders - hoe om te leer deur middel van musiekterapie}

In 1968 het Richard Weber se revolusionêre musiek-onderrigmetode 'n nuwe wêreld vir vertraagde kinders oopgestel, naamlik deur middel van die Musical Method. ${ }^{5}$.

Die kind het beheerbaar geword en dit het vir hom moontlik geword om met hierdie metode te leer. Die kind het met die letters C D E F G $A \quad B$ begin en wysies gespeel wat net hierdie letters ingesluit het nadat die name van die letters op die betrokke note geplaas is. In werklikheid kan 'n hele aantal wysies op hierdie note gespeel word. 'n Agttien-jarige geestesvertraagde seun is geleer om te leer deur die orrel en die xilofoon te gebruik vir sy spesifieke leergebrek wat bestaan het uit 'n onvermoë om letters vir woordvorming in die korrekte volgorde saam te stel ${ }^{6}$. Wysies kan ook met nommers geskrywe word en dan op 'n genommerde klavierbord gespeel word. Om te kan skrywe vereis motoriese beheer en dit word baie doeltreffend ontwikkel deur middel van die speel van musiekinstrumente. 'n Begrip van linker- en regterkant kan ook verkry word deur middel van verskillende bewegings met die linker- en regterhande en linker- en regtervoete uit te voer. Koördinasie kan ook verbeter word deur op 'n orrel van die linkerhand gebruik te maak vir akkoorde, die linkervoet vir pedale, die regterhand vir die melodie en die regtervoet vir die harde en sagte pedaal. Eenvoudiger musikale aktiwiteite bestaan byvoorbeeld uit die klap van hande (vir die ritme), simbale, voetpedale aan tromme of jazzsimbale.
Die spesiale bydrae van musiek tot fisiese gesondheid

Ritme is die groot energiegewende krag in musiek. Dit is al eeue lank bekend waar blaasorkeste gebruik is om marsjerende leërs te begelei. Die liggaam reageer op outomatiese wyse op die ritmiese musiek en beweeg spontaan. Die gebruik van die hele liggaam stimuleer die funksie van die afsonderlike liggaamsdele en verbeter ook die metaboliese prosesse.

Wanneer opgewekte musiek vir pasiënte gespeel word moet hulle die geleentheid gegee word om te beweeg. Klein seuntjies moet nie verplig word om stil te sit terwyl hulle van nature wil hardloop, spring en huppel op maat van die musiek nie. Hul bewegings kan volgens die musiek op 'n verbeeldingryke wyse beheer word deur hulle byvoorbeeld in twee rye langs mekaar op die grond te laat sit en te laat roei terwyl 'n bootliedjie soos Bootjie na Kammaland gesing word. Hulle kan op 'n bank spring wanneer Hansie Slim, berg wil klim gesing word en afspring en terughardloop na die beginpunt wanneer Hardloop gou-gou terug gesing word. Slaapliedjies, wiegeliedjies, bootliedjies en selfs stadige walse wat saggies gespeel word, kan gebruik word om hulle stil en ontspanne te hou. Ritmiese beweging is ' $n$ beheerde aktiwiteit wat vir die liggaam natuurlik is. Stadige en vinnige tempo's word bepaal volgens die polsslag en die spoed waarmee gestap word ${ }^{7}$.

Ontspanning is belangrik vir liggaamlike en verstandelike gesondheid en musiek kan 'n belangrike bydrae lewer, veral saans of as die weer ongunstig is. Goeie liggaamlike gesondheid verbeter die vermoë om te leer. Liggaamlike opvoeding vorm deel van enige opvoedingstelsel. Musiek is die motivering vir baie aktiwiteite, en die regte musiek op die regte tydstip dien as terapie.

\section{DOELSTELLINGS VAN MUSIEKTERAPIE}

Die psigiatriese doelstellings van musiekterapie is veral die volgende

- die vestiging of hervestiging van persoonlike verhoudings
- die ontwikkeling van selfagting deur middel van selfverwesenliking

- die gebruik van die unieke potensiaal van ritme as energiewekker en om ordelikheid te bevorder ${ }^{8}$.

\section{GEVOLGTREKKING}

Oriëntering wat betref die vermoë om te luister en tyd-beheerde gedrag is essensieel vir die opvoedkundige proses en vir enige vorm van opleiding, selfs al is dit opleiding in gedrag. Die bydrae van musiekterapie as 'n bykomende gesondheidsdiens is in hierdie artikel uiteengesit en daar word gehoop dat hierdeur getoon is dat beide terapie en opvoeding daadwerklik deur musiek gehelp kan word. Die terapeut is tevrede as die toepassing van sy of haar musiekopleiding gehelp het om die volgende teweeg te bring

- meer harmoniese gedrag in die rehabilitasiesentrum

- die moontlikheid dat die beste pasiënte in staat gestel word om, as gevolg van interpersoonlike verhoudinge deur musiek, die internasionale taal deur die eeue, op 'n aanvaarbare wyse by die buitewêreld aan te pas.

VERWYSINGS

1. Howery, B L in Gastron, E T (ed)Music in therapy Macmillan. New York 1968. p48

2. Thomas. E. et al: The efects of music therapy on a group of institutionalised mentally retarded boys. S.A. Medical Journal. Vol 48. p 1723 - 1728.

3. Schneider, J. Music, noise and hearing damage. S.A. Medical Joumal Vol 50. p 1912 - 1914

4. (a) Van Jaarsveld. P E Die oor en taal. Departement Psigologie. Potchefstroomse Universiteit vir C.H.O. 1975 (b) Ibid: The Effect of audio-psycho-phonology on stut lering. op cir. 1976.

5. Wylie, E. McL. Pied piper of education. The Reader Digest. November 1968. pp. 101, 102, 105, 106

6. Thomas, E. (1977) Unpublished paper: Alexandra Care and Rehabilitation Centre. Maitland.

7. McLaughlin, T Music and communication. Faber and Faber. London. 1970

8. Gastron, E T in Gastron E T (ed) Op cit p 5 